\title{
Research Paper Integrated farming system for livelihood security of small farmers of North- East Karnataka
}

See end of the paper for authors' affiliations

Correspondence to : S. N. VINODAKUMAR Department of Agronomy, University of Agricultural Sciences, RAICHUR (KARNATAKA) INDIA

\section{Paper History :}

Received : 21.03.2017;

Revised :03.07.2017;

Accepted : 17.07.2017
Abstract : Investigations were carried out in Main Agricultural Research Station (MARS), Raichur district of Karnataka during 2012-14 to find out a sustainable mixed farming model which is economically viable by integrating the different components like crops, livestock, poultry, rabbits and fish on a 2.5 acre land holding. Seven integrated farming system models were developed to find out the best package on the land holding of 2.5 acre suitable for the North- East Karnataka region. Among various IFS models, $\mathrm{F}_{7}$ model registered highest net returns (Rs. 1,89,069 ha/year) and least observed in conventional cotton alone $\left(\mathrm{F}_{1}\right)$ system (Rs. 74,592 ha/year). The similar trend was observed in return per day, diversity index and employment generation (Rs. 518/day, 2.92 and 206 mandays/ha/year).

Key Words : Cost, Diversity index, Employment, Integrated farming systems (IFS) modules, Returns

How To Cite This Paper : Vinodakumar, S.N., Desai, B. K., Channabasavanna, A.S., Rao, Satyanarayana, Patil, M.G. and Patil, S.S. (2017). Integrated farming system for livelihood security of small farmers of NorthEast Karnataka. Internat. Res. J. Agric. Eco. \& Stat., 8 (2) : 216-221, DOI : 10.15740/HAS/IRJAES/8.2/216221. 